\title{
IMPLEMENTASI KEBIJAKAN VISI DAN MISI PEMBANGUNAN PERIODE PERTAMA PEMERINTAHAN KOTA TIDORE KEPULAUAN
}

\author{
Idris Sudin \\ Dosen Fakultas Ilmu Sosial dan Ilmu Politik Universitas Nuku Tidore \\ Email: idrissudin.is@gmail.com
}

\begin{abstract}
The backround of vision policy implementation in this govermental development, was pushed by the duty of political elite leader for implementing their promise to societies through vision and mission presentation, so the power legitimation could be believed societies. This research explain about the implementation in developmental mission and vision Tidore Government during 2005-2010 years. More substansially, the aim that would be reached are to know the succes implementation model of George Edaward III, about communication, , resourch, bureaucratic structure and dissposition in making that vision and mission. Besides that, this thesis also want to study the policy implementation failure in Tidore developmental programe. The model that uses is Merille Gerindle model, foccused that an implementation is failure because two factors, namely: (1) it relates with the policy contents, (2) and, it relates with the public policy environment.

Methode that used in this research is qualitative research model. The data analysis model, according to Miles Huberman in this research describing three analysis rank (1) data reduction, (2) data presentation, (3) Conclussion result. The research result showed that several field communication in implementing vision and mission like religion and indepence by self-regulating that exist or according with RPJMD developmental planning, , mass media, semiloka, form seminary, consolidation form, there is religion medium for civiz religious form. Resources are still lack, bureaucratic structural empowering is still weak. It insight by intervention behaviour and disfungtion between one part with the others.. Disposition is also still improved because low of commitmen, thrust, consistency in developmental implementation in Tidore Archipelago. Even the faile form policy implementation in order to make governmental programe indicates that policy makers and politital elite has big power to influence those implementation developmental programe implementation in Tidore Archipelago, because they determine the decission contents of those programes.

The Reccomendations mjust be improved in implemanting Governemntal developmental's vision and mission is to communicate those vission and and the really foccus. The improvement of human resources by practice and education wiyth step by step system for state apparatus in Tidore Government. Redesign of bureaucratic structure has aims in order to make open system and design management system toward simple of bureaucratic structure and make many function. People need ability improvement with commitmen, trust, consistency for doing government duty, with consider policy contents and policy environmental contex in the field area.
\end{abstract}

Key words: Implementation, vision/Mision, Programe Policy, and Development. 


\section{A. PE N D A H U L U A N}

\section{Latar Belakang}

Salah satu persoalan mendasar kehidupan bernegara khususnya dalam proses penyelenggaran pemerintahan, baik di tingkat pusat maupun daerah adalah bagaimana membangun atau menciptakan mekanisme pemerintahan yang dapat mengemban misinya untuk mewujudkan fungsi pemerintahan yaitu menyejahterakan masyarakat secara berkeadilan sebagaimana terformulasi dalam rumusan visi pemerintahan tersebut. Untuk mewujudkan kesejahteraan masyarakat, pemerintah harus melaksanakan pembangunan. Selain untuk memelihara keabsahannya (legitimasi), pemerintah juga akan dapat membawa kemajuan bagi masyarakatnya sesuai dengan perkembangan zaman.

Upaya perwujudan visi tersebut tentu melalui perumusan misi penyelenggaraan pemerintahan, dan secara praktis, implementasi misi penyelenggaraan pemerintahan dilakukan melalui tahapan formulasi kebijakan yang melahirkan program dan kegiatan pembangunan. Idealnya, dalam formulasi kebijakan dan implementasi harus terintegrasi dan konsisiten baik secara konseptual maupun penerapannya.

Darise (2008) mengatakan, bahwa dalam pelaksanaan pemerintahan dan pembangunan secara nasional, berdasarkan prinsip otonomi dan desentralisasi, pemberian kewenangan yang luas kepada daerah memerlukan koordinasi dan pengaturan untuk lebih mengharmoniskan dan myelaraskan pembangunan, baik pembangunan nasional, pembangunan daerah maupun pembangunan antar daerah. Berdasarkan pertimbangan ini, ditetapkan Undang-Undang Nomor 25 Tahun 2005 tentang Sistem Perencanaan Pembangunan Nasional. Undang-undang ini pada dasarnya mengamanatkan bahwa perencanaan pembangunan daerah adalah satu kesatuan dalam sistem perencanaan nasional dengan tujuan untuk menjamin adanya keterkaitan dan konsistensi antara perencanaan, penganggaran, pelaksanaan, serta pengendalian dan pengawasan.

Undang-undang Nomor 25 tahun 2005 tentang Sistem Perencanaan Pembangunan Nasional, memiliki keterkaitan dengan Undang-undang Nomor 32 tahun 2004 tentang Pemerintah Daerah dan Undang-undang Nomor 17 tahun 2003 tentang Keuangan Negara. Produk hukum 
ini menegaskan dokumen perencanaan sebagai wujud administratif dari formulasi kebijakan pembangunan yang harus dibuat oleh pemerintah daerah, baik propinsi, kabupaten atau kota adalah: (1) Rencana Pembangunan Jangka Panjang Daerah (RPJPD); (2) Rencana Pembangunan Jangka Menengah Daerah (RPJMD); (3) Rencana Kerja Pemerintah Daerah (RKPD). Terdapat pula dokumen perencanaan yang dibuat oleh Satuan Kerja Pemerintah Daerah (SKPD) sebagai bentuk penjabaran, yaitu: (1) Rencana Strategis Satuan Kerja Perangkat Daerah (Renstra SKPD); (2) Rencana Kerja SKPD (Renja SKPD). Dokumen-dokumen perencanaan ini terkait satu dengan yang lainnya serta memiliki singkronisasi dengan dokumen perancanaan pembangunan Nasional.

Produk hukum tersebut, juga mengamanatkan kepada pemerintah daerah, agar dalam memformulasikan kebijakan perencanaan pembanguan harus konsisten pada sasaran mewujudkan visi pembangunan daerah dan tujuan pembangunan nasional. Karena konsistensi dalam implementasi kebijakan serta strateginya dapat menjamin terwujudnya Visi pembangunan daerah.
Kota Tidore Kepulauan sebagai bagian integral dari Negara Kesatuan Republik Indonesia memiliki kewajiban yang sama dalam hal pelaksanaan amanat Undang-Undang tersebut diatas. Sehubungan dengan penyelenggaraan pemerintahan Kota Tidore Kepulauan yang secara defenitif baru berlangsung pada periode pertama (2005-2010) dan periode kedua (2010-2015), maka penilaian atau evaluasi atas formulasi dan implementasi kebijakan yang tepat pada periode awal dapat memberikan arah yang semakin jelas bagi penyelengaraan pemerintahan dan pembangunan yang semakin baik pada masa depan.

Dengan dasar pemikiran yang telah diuraikan, penelitian ini dimaksudkan untuk: mengkaji proses implementasi dari kebijakan visi dan misi pembangunan pada periode pemerintahan tersebut, mengetahui sejauhmana konsistensi pemerintah daerah dalam memformulasikan kebijakan yang bersesuaian dengan upaya mewujudkan visi pembangunan dalam periode pemerintahan tahun 2005-2010. Selanjutnya menjelaskan tingkat capaian kinerja pembangunan pada periode pertama pemerintahan pasca pemekaran atau tepatnya perubahan status menjadi kota. 
Berdasarkan waktu pelaksanaannya, penelitian ini telah dilaksankan pada 'masa transisi' periode pemerintahan 2005-2010 dan 2010-2015 tepatnya pada akhir tahun 2009. Akan tetapi untuk tujuan penyebaran informasi atas bentuk evaluasi penyelenggaraan pemerintahan daerah, maka hasil penelitian ini diterbitkan pada jurnal edisi ini.

\section{Rumusan Masalah}

Rumusan masalah dalam penelitian ini adalah:

a. Bagaimana Implementasi kebijakan Misi Pembangunan Pemerintahan Kota Tidore Kepulauan dalam Periode 2005$2010 ?$

b. Faktor Apa saja yang mempengaruhi kegagalan Implementasi Kebijakan Pembangunan pemerintahan dalam mewujudkan misi Kota Tidore Kepulauan dalam Periode 2005-2010?.

\section{Tujuan Penelitian}

Penelitian ini bertujuan untuk:

a. mengetahui implementasi kebijakan misi pembangunan Kota Tidore Kepulauan dalam periode 2005-2010.

b. mengetahui dan menjelaskan faktor pengaruh atau penghambat dalam implementasi misi pembangunan Kota
Tidore Kepulauan pada periode 20052010.

\section{Manfaat Penelitian}

Diharapkan dengan penelitian ini dapat bermanfaat:

a. Sebagai referensi dalam pembelajaran tentang pembangunan.

b. Sebagai bahan evaluasi bagi para penyelenggara pemerintahan daerah dalam rangka penyelenggaraan pembangunan yang lebih baik pada masa depan.

\section{B. TINJAUAN PUSTAKA}

\section{Pengertian Kebijakan}

Penggunaan istilah kebijakan (policy) seringkali saling dipertukarkan dengan istilah tujuan (goals), program, keputusan, undang-undang, ketentuan-ketentuan, usulan-usulan, dan rancangan-rancangan besar.

Perserikatan Bangsa-bangsa (1975) (dalam Wahab, 1997: 2) memberi makna kebijakan berupa suatu deklarasi mengenai suatu dasar pedoman bertindak, suatu arah tindakan tertentu, suatu program mengenai aktivitas-aktivitas tertentu atau suatu rencana tertentu, suatu program mengenai aktivitas-aktivitas tertentu atau suatu 
rencana tertentu. Kebijakan pada intinya adalah sebagai pedoman untuk bertindak. Pedoman ini boleh jadi amat sederhana atau kompleks, bersifat umum atau khusus, luas atau sempit, kabur atau jelas, longgar atau rinci, kualitatif atau kuantitaif, publik atau privat.

Pengertian lain yang dikemukakan oleh Anderson (1997) bahwa kebijakan itu adalah "A purposive course of action followed by an actor or set actors in dealing with a problem or matters of concern" (serangkaian tindakan yang mempunyai tujuan tertentu yang diikuti dan dilaksanakan oleh seorang pelaku atau sekelompok pelaku guna memecahkan suatu masalah tertentu).

Dikemukakan oleh Easton (dalam Wahab, 1989: 21) secara singkat bahwa kebijakan adalah " $A$ policy ...consist of web of decisions and actions than allocate....values" (suatu kebijakan ....terdiri atas serangkaian keputusankeputusan dan tindakan untuk mengalokasikan....nilai-nilai).

Dari ketiga pendapat mengenai rumusan arti kebijakan, pada intinya setiap rumusan mengandung beberapa elemen yaitu : (1) adanya serangkaian tindakan; (2) dilakukan oleh seseorang atau sekelompok orang; (3) adanya pemecahan masalah; dan (4) adanya tujuan tertentu. Apabila keempat elemen tersebut dipadukan maka dapat diperoleh suatu pengertian bahwa kebijakan adalah serangkaian tindakan yang berisi keputusan-keputusan yang diikuti dan dilakukan oleh seseorang atau sekelompok orang guna memecahkan suatu masalah untuk mencapai tujuan tertentu.

Meskipun istilah itu dapat dilakukan secara umum, namun pada kenyataannya lebih sering dan secara luas dipergunakan dalam kaitannya dengan tindakan-tindakan atau kegiatan-kegiatan pemerintah serta perilaku negara pada umumnya, yang lebih dikenal dengan sebutan kebijakan negara (public policy).

Anderson (1979: 3) mengemukakan bahwa "public policies are those policies developed by governmental bodies and officials" (kebijakan negara adalah kebijakan-kebijakan yang dikembangkan oleh badan-badan atau pejabat-pejabat pemerintah). Dan yang terakhir yang dikemukakan oleh Jenkins (dalam Wahab, 1997: 4) bahwa kebijakan negara, yaitu " $A$ set of interrelated decisions taken by a political actor or group of actors concerning the selection of goals and the means of achieving them within a specified 
situation where these decisions should, in principle, be within the power of these actors to achieve" (serangkaian keputusan yang saling berkaitan, yang diambil oleh seorang aktor politik atau sekelompok aktor politik berkenaan dengan tujuan yang telah dipilih beserta cara-cara untuk mencapainya dalam suatu situasi dimana keputusan-keputusan tersebut ingin dicapai oleh para aktor tersebut).

Kebijakan negara, bagaimanapun rumusannya pada hakekatnya mengarah pada kepentingan publik (public interest), dengan mempertimbangkan nilai-nilai yang ada. Seseorang atau sekelompok orang aktor politik (administator publik) harus senantiasa memasukkan pikiran-pikiran publik dalam wacana politiknya, dan bukan hanya pikirannya atau kemauannya sematamata sebagai dasar pengambilan keputusan. Dengan demikian, kebijakan negara dapat disimpulkan yaitu serangkaian tindakan yang dilakukan ataupun tidak dilakukan pemerintah, baik yang dilakukan oleh seorang atau sekelompok orang untuk mencapai suatu tujuan tertentu yang berorientasi pada kepentingan masyarakat (publik). Berkaitan dengan pengertian kebijakan negara, Islamy (1997: 20) merumuskan beberapa elemen penting tentang kebijakan negara (public policy), yaitu:

a. Bahwa kebijakan negara itu dalam bentuk perdananya berupa penetapan tindakan-tindakan pemerintah.

b. Bahwa kebijakan negara itu tidak cukup hanya dinyatakan tetapi dilaksanakan dalam bentuknya yang nyata.

c. Bahwa kebijakan negara baik untuk melakukan sesuatu atau tidak melakukan sesuatu itu mempunyai dan dilandasi dengan maksud dan tujuan tertentu.

d. Bahwa kebijakan negara itu harus senantiasa ditujukan bagi kepentingan seluruh anggota masyarakat.

\section{Implementsi Kebijakan}

Menurut Edwards III yang dikutip oleh Widodo (2009: 96), implementasi kebijakan di pengaruhi oleh empat variable yang saling berhubungan, yakni:

komunikasi (communication),

sumberdaya (resources), (3) disposisi (dispositions), dan (4) struktur birokrasi bureaucratic strukture). Keempat variabel ini, lebih lanjut dijelaskan oleh Subarsono (2008: 90-92) sebagai berikut:

Pertama, Komunikasi. Keberhasilan implementasi kebijakan masyaratkan agar implementor mengetahui apa yang harus di lakukan. Tujuan dan sasaran kebijakan 
harus ditransmisikan kepada kelompok sasaran (target group) untuk mengurangi distorsi implementasi. Artinya apa bila tujuan dan sasaran satu kebijakan tidak jelas atau tidak di ketahui sama sekali oleh kelompok sasaran, maka kemungkinan akan terjadi resistensi dari kelompok sasaran.

Kedua, Sumberdaya. Meski isi kebijakan dikomunikasikan secara jelas dan konsisten, tetapi implementor kekurangan sumberdaya untuk melaksanakan, maka implementasi tidak akan berjalan efektif. Sumberdaya tersebut mencakup sumberdaya manusia, yakni kompetensi implementor, dan sumberdaya financial.

Ketiga, Disposisi. Berkaitan dengan watak dan karakteristik yang dimiliki oleh implementor, seperti komitmen, kejujuran, dan sifat demokratis. Apabila implementor memiliki disposisi yang baik, maka dia akan dapat menjalankan kebijakan dengan baik seperti apa yang di inginkan oleh pembuat kebijakan. Keempat, Struktur organisasi, yang bertugas mengimplementasikan kebijakan memiliki pengaruh yang signifikan terhadap implementasi kebijakan. Salah satu dari aspek struktur yang penting dari setiap organisasi adalah adanya prosedur operasi yang standar (standard operating procedures atau SOP). SOP menjadi pedoman bagi setiap implementor dalam bertindak. Struktur organisasi yang terlalu panjang akan cenderung melemahkan pengawasaan.

\section{Faktor Yang mempengaruhi kegagalan Implementasi}

Menurut Grindle, yang dikutip oleh Nugroho (2006: 132) keberhasilan inplementasi kebijakan dipengaruhi oleh dua variable bersar, yaitu isi kebijakan (contet of policy) dan lingkungan implementasi (context of implementation). Ide dasar dari teori ini adalah setelah kebijakan ditransformasikan, maka langkah selanjutnya adalah melakukan inplementasi kebijakan. Keberhasilan implementasi kebijakan ditentukan oleh sejaumanah derajat (implementability) kebijakan tersebut. Uraian Teori ini:

Pertama, variable isi, yang meliputi: (1) kepentingan yang ter-pengaruhi oleh kebijakan. sejauh mana kepentingan kelompok sasaran (target grops) termuat dalam isi kebijakan. (2) jenis manfaat yang akan dihasilkan. (3) derajat perubahan yang diinginkan, atau sejauh mana perubahan yang diinginkan dari sebuah kebijakan. (4) kedudukan pembuat kebijakan. apakah letak sebuah program sudah tepat. (5) 
pelaksana program, apakah sebuah kebijakan telah menyebutkan implementatornya dengan rinci. (6) Sumber daya yang memadai.

Kedua variable implementasi, yang meliputi: (1) kekuasaan, kepentingan, dan strategi aktor yang terlibat. Seberapa besar kekuasaan, kepentingan, dan strategi yang dimiliki oleh para actor yang terlibat dalam implementasi kebijakan. (2) karakteristik lembaga dan penguasa. (3) kepatuhan dan daya tanggap kelompok sasaran.

Implementasi merupakan suatu proses untuk mewujudkan tujuan-tujuan yang telah dipilih dan ditetapkan sebelum menjadi kenyataan. Namun, tidak semuanya program yang diimplementasikan benar-benar berlangsung mulus dan efektif, karena ada faktor-faktor yang mempengaruhi keberhasilan implementasi kebijakan. Dalam proses kebijakan selalu terbuka kemungkinan adanya perbedaan antara harapan pembuat kebijakan dengan apa yang senyatanya dicapai. Keadaan ini oleh Dunsire (1978) dalam Wahab (1997: 61) dinamakan implementation gap. Besar kecilnya perbedaan tersebut sedikit banyak akan tergantung pada apa yang oleh William (1971; 1975) dalam Wahab (1997: 61) disebut sebagai implementation capacity dari organisasi/aktor atau kelompok organisasi/aktor yang dipercaya untuk mengemban tugas mengimplementasikan kebijakan tersebut.

Secara obyektif, bahwa kebijakan negara mengandung resiko untuk gagal. Pengertian kegagalan kebijakan negara oleh Hogwood dan Gunn (1986) dalam Wahab (1997: 61-62) dibagi ke dalam dua kategori, yaitu: (1) Non Implementation (tidak terimplementasikan), ini mengandung beberapa berupa: Kebijakan itu tidak dilaksanakan sesuai dengan rencana; Pihak-pihak yang terlibat dalam kebijakan tidak mau bekerjasama; Bekerjanya tidak efisien; Tidak menguasai permasalahan dan diluar jangkauan kekuasaan; atau Hambatan-hambatan yang ada tidak sanggup ditanggulangi. (2) Unsuccesful Implementation (Implementasi yang tidak berhasil)

Inipun mengandung alasan berupa: Kondisi eksternal tidak menguntungkan; Kebijakan tersebut tidak berhasil mewujudkan dampak atau hasil akhir yang dikehendaki.

Kebijakan yang gagal biasanya disebabkan oleh beberapa faktor: (1) pelaksanaannya memang jelek (bad execution), dalam arti pelaksana tidak 
memiliki keahlian sesuai dengan tuntutan kebijakan; (2) Kebijakannya tidak mencerminkan kepentingan rakyat atau kebijakannya jelek (bad policy), dan atau (3) karena tidak sesuai dengan harapan rakyat maka kebijakan itu memang bernasib jelek (bad luck) (Wahab, 1997)

Apabila suatu kebijakan yang diimplementasi mengalami kegagalan, maka dapat menimbulkan pertanyaan mengapa kegagalan itu dapat terjadi. Mengetahui sebab kegagalan, dapat memberi penjelasan tentang bagaimana cara mengatasinya dan implementasinya dapat dikembangkan. Sebab kegagalan implementasi suatu kebijakan berbeda antara satu kebijakan dengan kebijakan yang lain. Hal ini berkaitan dengan beberapa aspek sebagaimana yang dikemukakan oleh Maarse (dalam Wahab, 1997), yaitu (1) isi dari suatu kebijakan yang akan diimplementasikan, (2) tingkat informasi dari pelaku yang terlibat, (3) banyaknya dukungan bagi kebijakan yang diimplementasikan, dan (4) pembagian potensi.

\section{Pengertian Pembangunan}

Pembangunana adalah proses perubahan yang meliputi seluruh dimensi kehidupan masyarakat, baik ekonomi, politik, infrastruktur, social, budaya, pertahanan dan teknologi. Portes (1976), mendefenisiskan pembangunan sebagai transformasi ekonomi, social dan budaya. Pembangunan nasional adalah proses perubahan (transformasi) yang direncanakan untuk memperbaiki berbagai aspek kehidupan masyarakat kearah yang diinginkan, melalui kebijakan strategi dan rencana. Perubahan atau transformasi dalam struktur ekonomi, misalnya, dapat dilihat dari adanya peningkatan atau pertumbuhan produksi yang cepat disektor industri dan jasa, sehingga kontribusinya terhadap pendapatan nasional semakin besar. Sebaliknya, kontribusi sektor pertanian akan menjadi semakin kecil dan berbanding terbalik dengan pertumbuhan industrialisasi dan modernisasi ekonomi.

Secara umum dapat dipahami bahwa pembangunan adalah perubahan social, sedangkan perubahan social tidak selalu identik dengan pembangunan. Dalam konteks ini pembangunan adalah perubahan yang direncanakan, disengaja dan diinginkan untuk mencapai tujuan tertentu.

Karakteristik yang cukup penting dalam pembangunan adalah adanya kemajuan/perbaikan (progress), pertumbuhan dan difersifikasi. Kemajuan 
misalnya, dapat diidentifikasi dari adanya peningkatan dalam rasionalisasi kehidupan masyarakat, teknologi dan efisiensi. Sedangkan pertumbuhan identik dengan kemajuan ekonomi yang ditandai oleh peningkatan pendapatan masyarakat sebagai akibat dari pertumbuhan produktifitas dan diikuti oleh diversifikasi kegiatan ekonomi, baik vertikal maupun horizontal. Dengan demikian, pembangunan memiliki tiga ciri dasar, yaitu pertumbuhan, diversifikasi/diferensiasi dan perbaikan (progress) yang terjadi pada semua aspek dan tingkat kehidupan masyarakat.

Variabel-variabel pembangunan berubah dengan kecepatan yang berbeda ditempat yang berbeda. Variabel pembangunan ini mencakup faktor-faktor primer seperti natioan building, atau penetaan kelembagaan, penurunan angka kelahiran dan kematian, pengurangan angka kemiskinan, pendidikan dasar, infrastruktur wilayah dan komunikasi, yang berorientasi pada pemenuhan berbagai kebutuhan dasar, seperti listrik masuk desa, pembukaan akses bagi wilayah yang terisolir, layanan kesehatan pedesaan dan harga makanan pokok yang rendah. Untuk negara atau wilayah yang telah dapat memenuhi kebutuhan tersebut, indikator pembangunan akan bergeser kepada fektorfaktor sekunder dan tersier, seperti: pertumbuhan ekonomi yang mendorong pemerataan, kesejahteraan dan peningkatan kualitas hidup; Menguatkan ekonomi nasional/domestik yang dapat memperluas lapangan kerja, sehingga daya beli masyarakat terus meningkat baik untuk barang lokal maupun inpor; Diversifikasi kegiatan/sektor ekonomi dengan penguatan sektor industri dan jasa disertai dengan keseimbangan antara produksi barang ekspor dan inpor; Partisipasi masyarakat dalam kehidupan politik dan proses pembuatan keputusan; Tersedianya kesempatan untuk memperoleh pendidikan bagi semua lapisan masyarakat. Stabilitas sosial, politik dan pemerintahan yang disertai dengan penguatan hak-hak azasi manusia.

Pembangunan dapat dibedakan menjadi pembangunan ekonomi (Economic development) dan pembangunan sosial (social development) Pembangunan ekonomi berkenaan dengan investasi, peningkatan penyerapan angkatan kerja, dan peningkatan upah buruh. Pembangunan ekonomi dapat dipahami sebagai proses dimana pemerintah bekerjasama dengan 
kelompok-kelompok masyarakat dan swasta dalam mengelola sumberdaya yang tersedia untuk menciptakan lapangan kerja dan menstimulasi kegiatan ekonomi. Pembangunan sosial berkenaan dengan pembangunan masyarakat secara menyeluruh, mencakup ekonomi, politik, budaya, hukum, kelembagaan, kesehatan, pendidikan dan dimensi-dimensi sosial lainnya. Didalamnya mencakup juga pemberdayaan sektor swasta dan masyarakat sipil, proses politik yang partisipatif dan akuntabel, pembangunan infrstruktur ekonomi dan sosial, termasuk pelayanan sosial yang memadai dan memuskan (Blakely, 2000).

Uraian ini mengarahkan bahwa tujuan pembangunan dapat dipahami sebagai akibat akhir dari seluruh upaya pembangunan. Sedangkan strategi atau perencanaan merupakan pilihan lintas sebab akibat yang secara sistematik dilakukan dan asumsi-asumsi yang diharapkan tersedia, agar tujuan pembangunan dapat tercapai (Indra Bastian, 2006).

Dalam penyelenggaran pemerintahan proses pembangunan pada setiap periode diharapkan dapat berkesinambungan. Dalam hal ini perumusan kebijakan harus memiliki singkronisasi dan pola hubungan yang jelas dalam setiap pentahapannya. Berkaitan dengan pemikiran ini, menurut Rahmat (2009), Sebuah kebijakan berhubungan dengan kebijakan terdahulu dan akan diikuti oleh kebijakan yang lainnya. Kerana kebijakan pada dasarnya adalah pedoman untuk bertindak guna mencapai tujuan. Tujuan dimaksud dapat diartikan sebagai visi pembangunan yang ditetapkan atau dicanangkan oleh pemerintah daerah.

Pada perspektif seperti ini, kebijakan harus pula didukung oleh suatu bentuk kekuasaan agar dapat memaksakan berbagai pihak terkait, baik unsur pemerintah, maupun komponen masyarakat yang terlibat selaku unsur pelaksana kebijakan untuk mengindahkan kebijakan tersebut sebagai pedoman. Suatu bentuk kekuasaan tersebut dapat dibentuk dengan menegaskan kebijakan tersebut sebagai bentukan produk hukum atau status keputusan yang memiliki kekuatan hukum mengikat bagi berbagai pihak. Penyertaan status kekuasaan bagi suatu kebijakan ini. Akan menjamin konsistensi pada tahapan implementasi dan sekaligus pada perumusan kebijakan selanjutnya. Untuk itu, terhadap visi sebagai tujuan dan 
kebijakan sebagai formulasi strategi untuk pencapaian visi yang harus memiliki singkronisasi dan konsistensi secara konseptual dibingkai pula dengan ketentuan hukum yang mengikat bagi berbagai pihak. Hal ini penting untuk memungkinkan konsolidasi organisasi, yang membawa pada suasana meningkatnya partisipasi dalam implementasi mewujudkan visi pembangunan tersebut (Brison, 2007).

Pemikiran diatas berhubungan dengan yang disampaikan Max Milikan dalam Myron Weiner, (1986): Bila kesempatan untuk mengecap hasil pembangunan dan turut serta dalam kegiatan pembangunan tidak disebarluaskan dalam masyarakat, maka akan timbul frustrasi yang membahayakan tingkat kestabilan minimum yang diperlukan bagi terlaksananya kebijakan pembangunan secara efektif.

\section{Perencanaan Pembangunan Daerah}

Konsep perencanaan Pembangunan bertujuan mengoptimalkan penggunaan potensi sekaligus mengurangi ketimpangan pembangunan antar daerah. Terdapat banyak masalah dalam pelaksanaannya, antara lain kurangnya konsistensi perencanaan hingga permasalahan dilapangan. Disamping itu, ruang gerak pemerintah daerah dalam perencanaan dan pengaturan pembangunan dengan perioritas sesuai potensi daerah yang terbatas.

Dalam Otonomi Daerah, berbagai aspek yang erat kaitannya dengan perencanaan pembangunan berkaitan dengan alokasi sumber daya, peningkatan peran masyarakat, potensi dan keanekaragaman daerah. Semua aspek tersebut dipadukan dalam satu kesatuan sistem pembangunan nasional (Indra Bastian, 2006).

\section{METODE PENILITIAN}

\section{Jenis penelitian}

Jenis penelitian ini adalah penelitian kwalitatif dengan metode deskriptif. Menurut Hasan, 2002, Deskriptif artinya melukiskan variabel demi variabel, satu demi satu berdasarkan rumusan masalah. Metode deskriptif ini digunakan dengan tujuan:

a. Mengumpulkan informasi aktual secara rinci, yang melukiskan gejala yang ada,

b. Mengidentifikasi masalah atau memeriksa kondisi dan praktek-praktek yang berlaku,

c. Membuat perbandingan atau evaluasi 
d. Menentukan apa yang dilakukan orang lain atau lembaga lain dalam menghadapi masalah yang sama dan belajar dari pengalaman mereka untuk menetapkan rencana dan keputusan pada waktu yang akan datang.

Dengan demikian, metode deskriptif ini digunakan untuk melukiskan secara sistematis fakta atau karakteristik bidang tertentu secara aktual dan cermat, dalam hal ini bidang perencanaan pembangunan di Kota Tidore Kepulauan.

\section{Desain Penelitian}

Dari jenis penelitian tersebut diatas, penelitian ini dilakukan dengan desain deskriptif. Desain ini bertujuan untuk menguraikan sifat atau karakteristik dari suatu fenomena tertentu. (Hasan, 2002) mengemukakan bahwa tujuan dari desain ini hanya mengumpulkan fakta dan menguraikannya secara menyeluruh dan diteliti sesuai dengan persoalan yang akan dipecahkan. Dengan demikian penelitian ini diharapkan dapat mengurai karakteristik dari fenomena implementasi kebijakan misi sebagaimana rumusan masalah berdasarkan hasil pengumpulan fakta, yang selanjutnya penarikan kesimpulan didasarkan pada penguraian fakta tersebut.

\section{Tempat dan Waktu Pelaksanaan Penelitian}

Penelitian ini dilaksanakan di Kota Tidore Kepulauan dengan latar penelitian pelaksanaan pemerintahan pada periode 2005 sampai dengan 2010, sebagai bentuk evaluasi terhadap penyelenggaraan pemerintahan pada periode awal pembangunan daerah yang baru dibentuk. Adapun waktu pelaksanaan penelitian ini adalah selama 2 (dua) bulan, terhitung sejak bulan September 2009 sampai dengan bulan November 2009.

\section{Subjek Penelitian}

Subjek penelitian ini terdiri dari komponen atau unsur perumus dan pengambil kebijakan serta beberapa dari unsur pelaksana kebijakan, berdasarkan rumusan masalah dalam penelitian ini. Unsur perumus dan pengambil kebijakan terdiri dari unsur DPRD, Kepala Daerah, Badan Perencanaan Pembangunan Daerah. Sedangkan unsur pelaksana Kebijakan Kepala SKPD yang diambil secara random.

\section{Variabel atau Objek Penelitian}

Rumusan visi dan misi pelaksanaan pembangunan, agenda pokok, kabijakan umum dan perioritas program dalam rangka mewujudkan visi pembangunan, yakni terdiri dari: dirumuskan pada setiap tahun 
terhitung sejak tahun pertama penyelenggaraan tugas pemerintahan definitif Kota Tidore Kepulauan (tahun 2005-2010).

\section{Sumber Data}

Berdasarkan sumber pengambilannya, data penelitian terdiri dari:

a. Data Primer yaitu data yang bersumber langsung dari penelusuran pada pelaku atau perumus dan pelaksana kebijakan pada periode pemerintahan tersebut, serta dari unsur masyarakat. Sumber data yang dimaksudkan sebagai informan diantaranya (Wali Kota Tidore Kepulauan, Sekertaris Bappeda Kota Tidore Kepulauan, Unsur DPRD, dan Sekertaris Kota Tidore Kepulauan).

b. Data Sekunder bersumber dari penelusuran dokumen pada instansi pemerintah daerah yang terkait. Dokumen dimaksud adalah dokumen yang yang berisikan kebijakan perencanaan pembangunan daerah Kota Tidoere Kepulauan

7. Teknik dan Instrumen Pengumpulan Data

Teknik pengumpulan data primer dilakukan dengan 2 (dua) cara: a. Dengan menggunakan pedoman wawancara yang memuat pertanyaan untuk memunculkan jawaban dalam bentuk pernyataan dari informan yang terdiri dari pelaku atau perumus pelaksana kebijakan serta dari unsur masyarakat.

b. Dengan menggunakan instrument wawancara (interview). Dimana pengumpulan data dilakukan dengan mengajukan pertanyaaan langsung kepada informan, dengan memberikan kebebasan kepada informan untuk memberikan jawaban dan pernyataan sesuai dengan keinginannya berdasarkan rumusan masalah penelitian.

Untuk pengumpulan data sekunder dilakukan dengan teknik Studi Dokumentasi, yaitu teknik pengumpulan data yang tidak langsung ditujukan pada subyek penelitian, melalui dokumen. Dokumen dimaksud adalah dokumendokumen perencanaan pembangunan daerah Kota Tidore Kepulauan yang terdiri dari:

a. Dokumen Rencana Pembangunan Jangka Panjang Daerah

b. Dokumen Rencana Pembangunan Jangka Menengah Daerah 
c. Dokumen Rencana Kerja Pemerintah Daerah

d. Dokumen Peraturan Daerah tentang Anggaran Pendapan dan Belanja

Daerah

Keseluruhannya adalah dakomentasi dari tahun 2005 sampai dengan 2009.

\section{Keabsahan Data}

Untuk mendata keabsahan data diperlukan teknik pemeriksaan. Pelaksanaan teknik pemeriksaan didasarkan atas sejumlah kriteria,ada empat kriteria yang digunakan dalam penelitian ini yaitu :

\section{(1). Derajat kepercayaan (credibility)}

Dalam penelitian ini peneliti mengikuti beberapa cara yang dapat disamakan dengan uji validitas agar kebenaran hasil penelitian dapat dipercaya, misalnya:

a. Ketekunan pengamatan: dengan ketekunan peneliti menemukan situasi dan informasi yang relevan dengan fokus penelitian sehingga peneliti dapat memperoleh data dan informasi secara cermat,terinci dan mendalam.

b.Triangulasi: Melakukan pengumpulan data sekaligus menguji kredibilitas data tersebut dengan teknik pengumpulan dan sumber data yang berbeda. c. Pengecekan sejawat, ini dilakukan untuk membuat peneliti tetap mempertahankan sikap terbuka dan kejujuran,peneliti dapat mereview persepsi,pandangan dan analisis yang sedang peneliti lakukan.

d. Kecukupan referensial. Bahan referensi digunakan untuk dapat meningkatkan derajat kepercayaan dan kebenaran data, yaitu hasil rekaman tape atau bahan dokumentasi lainnya, termasuk foto.

\section{(2). Keteralihan (transferability)}

Dalam penelitian ini peneliti membangun nilai transfer penelitian dengan cara melaporkan hasil penelitian seteliti dan secermat mungkin agar semua pihak dapat memahami temuan-teman yang diperoleh peneliti.

\section{(3). Ketergantungan (dependability)}

Dilakukan untuk menilai apakah proses penelitian bermutu atau tidak yang dihubungkan dengan pemeriksaan dari hasil-hasil data yang akan diperoleh di lapangan. Dependability menurut istilah konvensional disebut dengan reability atau reabilitas. Reabilitas adalah syarat syarat bagi validitas,hanya dengan alat yang reliable maka diperoleh data yang valid. Alat utama dalam penelitian naturalistik ini adalah peneliti sendiri. 
Untuk menjamin kebergantungan dan kepastian yang perlu dilakukan adalah menyatukan dependability dengan confimability,hal ini dikerjakan melalui suatu cara yang disebut audit trail (memeriksa dan melacak suatu kebenaran) yaitu suatu usaha yang lasim dilakukan oleh akuntan pemeriksa keuangan. Proses audit trail ini dikuti dalam usaha untuk menjamin kebenaran penelitian naturalistic, pada penelitian tesis ini audit trail dilakukan oleh pembimbing. Dalam hal ini yang diperiksa antara lain : proses penelitian, taraf kebenaran data serta tafsiran.

\section{(4).Kepastian (confirmabilty)}

Dalam penelitian ini merupakan usaha ilmiah yang dilakukan oleh peneliti dengan cara disiplin yang terikat dengan kaidah penelitian kualitatif dan terbuka bagi pemeriksa dan verifikasi oleh orang yang berminat untuk menilai kualitas hasil penelitian dengan menguji apakah data yang ada hasilnya tetap stabil.

Selanjutnya menurut (Hamdi, 2004:83 ) untuk membuktikan data atau informasi yang telah dikumpulkan dalam suatu penelitian kualitatif perlu diuji keabsahannya melalui teknik-teknik triangulasi sebagai berikut : a. Triangulasi teknik: Peneliti melakukan pengambilan data sekaligus menguji kebenaran data dengan cara melakukan pengumpulan data dengan teknik pengumpulan yang berbeda pada sumber yang sama.

b. Triangulasi sumber: melakukan pengumpulan data dari sumber yang berbeda dengan teknik yang sama.

c. Triangulasi situasi: Melakukan pengumpulan data sekaligus menguji kredibilitas data dengan perbedaan waktu dan situasi peangambilan data pada sumber yang sama.

\section{Teknik Analsis Data}

Analisis data adalah proses mengorganisasikan dan mengurutkan data kedalam pola, kategori dan satuan uraian dasar, sehingga dapat ditemukan tema dan dapat dirumuskan hipotesis kerja. Disarankan oleh (Moleong,2004:280) yaitu observasi, wawancara, dokumentasi, dan catatan lapangan, dibaca, dipelajari dan ditelaah maka langkah berikutnya adalah dianalisis dengan langkah-langkah sebagai berikut

\section{a. Reduksi Data}

Data yang diperoleh dari lapangan disusun dalam bentuk uraian atau laporan yang terrinci. Laporan-laporan tersebut 
direduksi, dirangkum, dipilih hal-hal pokok, difokuskan pada hal-hal penting, dan disusun lebih sistematis. Untuk keefektifan penelitian, data segera dianalisis selama pengumpulan data dan setelah data terkumpul.

b. Penyajian data

Penyajian data merupakan proses penysunan informasi yang kompleks kedalam bentuk yang sistemtis,sehingga menjadi lebih sederhana dan selektif serta dapat dipahami maknanya. Penyajian data dimaksudkan untuk memperoleh temuantemuan bermakna, serta memberikan kemungkinan adanya penarikan kesimpulan dan pengambilan tindakan.

c. Menarik kesimpulan/verifikasi

Berdasarkan data-data dari berbagai sumber,peneliti mengambil kesimpulan yang bersifat mendasar "grounded". Dengan kata lain kesmpulan harus senantiasa diverivikasi selama penelitian berlangsung (Nasution 2003:129).

\section{DESKRIPSI WILAYAH PENELITIAN}

\section{Sejarah Singkat Kota Tidore Kepulauan}

Perkembangan Kota Tidore dimulai dari sejarah Kesultanan. Pulau Tidore merupakan pusat dari Kesultanan Tidore, bersanding dengan Kesultanan Ternate, Jailolo dan Kesultanan Bacan. Keempat Kesultanan ini memiliki pertalian kekerabatan sebagai kakak beradik, yang membentuk persatuan kerajaan di Maluku Utara dengan sebutan "Maloku Kie Raha". Persatuan ini tangguh dalam melawan penjajah.

Di daerah ini, etika dan kultur keIslam-an merupakan landasan utama dalam menata struktur kesultanan maupun rumah tangga. Tatanan ke-Islaman ini muncul dalam istilah" Adat yang bersendikan agama dan agama bersendikan Kitabullah". Istilah berpengaruh terhadap aktifitas masyarakat yang sangat dipengaruhi oleh agama.

Masyarakat Tidore juga memiliki keragaman bahasa yang terdiri dari beberapa dialeg. Sikap mental yang sangat menonjol dalam kehidupan sehari-hari adalah tolong menolong dalam berbagai hal, seperti pembangunan rumah acara perkawinan maupun penagnan musibah sesama warga. Sikap ini sangat terpelihara dengan baik, sehingga dalam kehidupannya nampak pada beberapa adat dan kebiasaan 
yang bersifat sosial, seperti Bari (kerja sama mebantu dengan sukarela), Mayae Keterbukaan meminta bantuan sukarela, dan Marong (tolong menolong dalam hal membersihkan kebun dan membangun rumah).

Pada fase awal kemerdekaan, daerah ini adalah Ibukota Perjuangan Irian Barat Tahun 1956 dengan Gubernur Pertama Sultan Zainal Abidin Syah yang juga Sultan Tidore. Daerah ini dikembalikan ke Provinsi Maluku sebagai Daerah Administratif Tidore pada Tahun 1962 Kepres No, 1 Tahun 1962. Perubahan nama Administratif Tidore menjadi Halmahera Tengah sesuai Surat Edaran Gubernur Maluku Tanggal 8 Juli 1969.

Berdasarkan UUD No. 6 Tahun 1990 ditetapkan sebagai Daerah Otonom Tingkat II Halmahera Tengah. Berdasarkan Undang-Undang No. 1 Tahun 2003 Kabupaten Halmahera Tengah dimekarkan menjadi Kabupaten Halmahera Tengah dengan Ibukota di Weda, Kabupaten Halmahera Timur di Maba dan Tidore yang semula sebagai ibu kota kabupaten Halmahera tengah bentuk sebagai daerah tersendiri berstatus kota dengan nama Kota Tidore Kepulauan.
Tanggal 31 Mei 2003 Gubernur Maluku Utara melantik Drs. M,Nur Djauhari sebagai penjabat Walikota Tidore Kepulauan.

Tahun 2005 Daerah ini memulai pemerintahan defenitif periode pertama. Tepatnya tanggal 8 Nofember 2005 Gubernur Maluku Utara atas nama Menteri dalam Negeri Melantik Drs. H. Achmad Mahifa dan Salahuddin Adrias, ST sebagai Walikota dan Wakil Walikota definitif periode 2005-2010 (Hasil Pilkada Tidore Kepulauan Tahun 2005).

Dalam Rencana Tata Ruang Wilayah(RTRW) Nasional, kawasan yang kini menjadi Kota Tidore Kepulauan, ditetapkan sebagai kawasan budidaya dengan pengembangan prioritas. Kemudian dalam struktur RTRW Provinsi Maluku Utara, Kota Tidore Kepulauan ditetapkan sebagai "Kota Orde 1" . Dengan penetapan tersebut, maka Kota Tidore Kepulauan merupakan kota yang penting dan strategis di Indonesia. Di wilayah provinsi Maluku Utara, posisi Kota Tidore Kepulauan merupakan Kota terluas dan bahkan bersifat strategis secara politis yakni karena kawasan pusat pemerintahan Provinsi yaitu di Sofifi (Kecamatan Oba 
Utara), secara administratif wilayah dari Kota Tidore Kepulauan.

\section{Luas Wilayah, Letak Geografis dan} Jumlah Penduduk

Luas wilayah Kota Tidore Kepulauan adalah $13857,20 \mathrm{~km} 2$, berada pada batas astronomis $0^{0}-20^{0}$ Lintang Utara hingga $0^{0}$ - $50^{\circ}$ Lintang Selatan dan pada posisi $127^{0} 10^{\prime}-127^{0} 45^{\prime}$ Bujur Timur. Kota ini berciri kepulauan, didalamnya terdapat 12 pulau dengan total luas daratan 1.550,37 $\mathrm{km}^{2}$, terdiri dari 8 kecamatan dan 91 Kelurahan/Desa. Berbatasan dengan Kabupaten Halmahera Barat disebelah utara, dengan Kabupaten Halmahera Selatan di sebelah selatan, dengan Halmahera Timur dan Halmahera Tengah di sebelah timur, serta berbatasan dengan Kota Ternate di sebelah barat. Jumlah Penduduk Kota Tidore Kepulauan sebanyak 92.226 jiwa.

\section{Visi dan Misi}

Sebagai wujud implementasi amanat Undang-Undang nomor 32 tahun 2004 tentang Pemerintahan Daerah, Pemerintahan periode awal Kota Tidore Kepulauan memformulasikan kebijakan otonomi yang diarahkan untuk mempercepat terwujudnya kesejahteraan masyarakat melalui peningkatan pelayanan, pemberdayaanan masyarakat serta mendorong peran swasta dalam pelaksanaan pembangunan. Formulasi kebijakan otonomi ini, tertuang dalam Rencana Pembangunan jangka Menengah Daerah(RPJMD) Kota Tidore Kepulauan Tahun 2005-2010 yang menetapkan visi pemerintahan yakni: "Menciptakan Kota Tidore yang beriman, maju, mandiri dan berperadaban". Dimana masing masing jargon pada visi tersebut terincikan dalam bentuk agenda pelaksanaan pembangunan pada setiap tahun dalam periode pertama pemerintahan 2005-2010. Uraian visi tersebut adalah sebagai berikut:

Beriman: Terpatrinya agama sebagai landasan berpikir dan bertindak dalam kehidupan individu, keluarga, lingkungan, pemerintahan dan umum.

Maju: Meningkatkan kualitas sumberdaya manusia yang memiliki kemampuan (skill), memahami tugas dan tanggungjawabnya, energik, inovatif dan berkepribadian.

Mandiri: Tersedianya infastruktur wilayah yang mendukung aksesibilitas sosial dan ekonomi, tersedianya lapangan kerja, meningkatnya produktifitas serta 
terpenuhinya kebutuhan-kebutuhan dasar masyarakat.

Berperadaban:

Terciptanya

kedamaian sosial atas dasar toleransi dan penghormatan terhadap kelembagaan sosial serta diperankannya institusi adat sebagai pilar pembangunan.

Berdasarkan visi pembangunan tersebut, ditetapakn misi pembangunan Kota Tidore Kepulauan adalah sebagai berikut:

1) meningkatkan kualitas keberagamaan dilingkungan masyarakat dan pemerintahan.

2) meningkatkan kualitas SDM melalui pelayanan pendidikan dan kesehatan ,pembinaan aparatur pemerintah Daerah, pembinaan keperempuanan, kepemudaan dan Olah Raga.

3) meningkatkan pembangunan infrastruktur sosial, ekonomi, dan pemerintahan serta pengembangan kawasan strategis dan cepat tumbuh berdasarkan rencana tata ruang wilayah Kota Tidore Kepulauan.

4) meningkatkan pembiayaan pembangunan dengan mengoptimalisasi pengelolaan sumber-sumber pendapatan Daerah dan peningkatan peran serta kelompok usaha mikro, kecil dan menengah (UMKM)

5) merefitalisasi nilai-nilai" adat se atorang" beserta kelembagaannya serta mewujudkan kehidupan masyarakat yang aman, damai, harmonis, dan berkepribadian.

\section{E. HASIL PENELITIAN DAN INTERPRETASI DATA}

Keberhasilan suatu kebijakan yang diusung pemerintah memiliki karakteristik dan model yang berbeda. Dimana dalam konteks kebijakan publik keberhasilan suatu kebijakan terletak pada unsur implementasi oleh pemerintah yang sedang membangun daerahnya atau sedang mewujudkan misi pembangunan pemerintahan. Pada bagian ini menjelaskan perihal implementasi misi dengan menggunkan model George Edward III (komunikasi, sumber daya, disposisi, dan struktur birokrasi) dan faktor keberhasilan maupun kegagalan oleh Model Merille Gerindle (isi kebijakan dan konteks implementasi).

\section{Dimensi Komunikasi}


Untuk mewujudkan misi pembangunan tentunya pemerintah Walikota Tidore Kepulauan memiliki cara dan strategi untuk mengkomunikasi mengenai hal-hal yang terkait dengan misi tersebut. Salah satunya bagaimana mengkomunikasikan Tidore kepulauan yang beriman, mandiri dan berperadaban. Sebagai visi dan misi ini menurut Walikota Tidore Kepulauan (H.Achmad Mahifa) mengatakan bahwa:

(1)Melalukan koordinasi aktor pelaku pembangunan untuk persamaan persepsi, (2)Sosialisasi kemasyarakat melalui pelaksana kegiatan pemerintahan secara teknis, dimana ada musrembang dari tingkat Desa, Kelurahan, Kecamatan , Kabupaten dan Kota kemudian rapat kerja perencana pemerintahan dibawah ke forum konsolidasi dan komunikasi visi dan misi dari program pembangunan (wawancara, $10 / 10 / 09$ ).

Selain yang dijelaskan Walikota diatas, maka proses mengkomunikasikan misi pembangunan Kota Tidore Kepulauan ditambahkan oleh Sekertaris Bappeda Kota Tidore Kepulauan (Fatharudun Soleman ) dalam bentuk dan cara yang berbeda untuk menyampaikan masalah keimanan, kemandirian dan berperadaban, bahwa:
Selain rapat koordinasi,maka yang harus dilakukan adalah rapat kerja pemerintah, rapat pembuatan KUA/PPAS, rapat Koordinasi penyusunan APBD. Sementara itu, sosialisasi bagi publik lebih melihat pada dokumen perencanaan melalui lokakarya, seminar, dan media (wawancara, 10/10/09).

Untuk mencapai target dari misi ini, secara ideal harus sesuai antara rumusan misi dengan implementasi kebijakan pembangunan dilapangan. Hal ini perlu dituangkan dalam kerja-kerja pemerintahan untuk mewujudkan masyarakat Tidore Kepulauan yang memiliki keimanan kepada Tuhan, kemandirian dalam melakukan berbagai aktivitas pemberdayaan, dan bahkan berperadaban untuk melihat kepentingan-kepentingan daerah dan masyarakat. Hal ini juga dijelaskan Unsur Dewan Perwakilan Rakyat Kota Tidore Kepulauan bahwa:

Sosialisasi dan komunikasi visi dan misi tersebut melalui program dan kegiatan setiap SKPD atau strategi kerja pembangunan daerah" (wawancara, 12/10/09).

Dimensi keimanan, kemandirian dan peradaban masih dalam konteks konsep yang diusahakan agar tujuan misi ini dapat dilaksanakan secara bijaksana oleh 
pemerintahan yang sedang digalakkan. Implementasi kebijakan ini bertujuan untuk melindungi dan memberikan kemananan bagi penganut agama yang hidup rukun dan damai dilingkungan pemerintahan Tidore Kepulauan.

Namun yang menjadi perhatian dari komunikasi keberagamaan ini adalah mempertimbangkan kualitas dilingkungan masyarakat, hal ini dikatakan Sekertaris Daerah Kota Tidore Kepulauan (Ibrahim Maradjabessy):

(1) Melaksanakan program/kegiatan yang mengarah pada peningkatan penghayatan ajaran agama dilingkungan masyarakat melalui pendidikan formal dan nonformal, (2) pembinaan wawasan keagamaan, (3) penataan lembaga keagamaan, (4) pembinaan keberagamaan antar umat beragama, (5) melakukan program peningkatan kesejahteraan (imam, syara'ah, pendeta dan petugas keagamaan lainnya (wawancara, 10/10/09).

Sasaran yang dicapai dari dimensi komunikasi dalam konteks agama bagi masyarakat Kota Tidore Kepulauan ini, tidak saja dilakukan dilembaga formaldan nonformal keagamaan namun dapat juga dilakukan melalui pembinaan antar umat beragama dalam meningkatkan kepedulian pemerintah untuk lebih mengefektifkan lembaga-lembaga keagamaan.

\section{Dimensi Sumber Daya}

Dalam melaksanakan visi dan misi pembangunan pemerintahan Kota Tidore Kepulauan, salah satu syarat adalah pengembangan sumber daya yang memadai, sehingga hal ini dapat digunakan sebagai landasan dalam penyelenggaraan pemerintahan di dearah. Sumber daya yang dimaksudkan ini tidak sekedar pada satu aspek yaitu sumber daya manusia akan tetapi juga sumber daya pendukung lainnya seperti infrastruktur lainnya yang mendukung implementasi kebijakan visi dan misi pembangunan Tidore Kepulauan.

Kualitas sumber daya manusia yang mendorong terwujudnya misi sehingga menciptakan kota Tidore Kepulauan yang bermartabat, mandiri, dan berperadaban, untuk meningkatkan kualitas sumber daya manusia harus dilakukan melalui beberapa aspek. Hal ini dikatakan unsur Dewan Perwakilan Rakyat Daerah (DPRD) Kota Tidore Kepulauan yang terkait dengan bidang kesehatan, pendidikan pembinaan aparatur pemerinahan menurutnya bahwa:

Masih rendahnya bidang pelayanan kesehatan diarahkan pada pembangunan Puskesmas di semua desa/kecamatan dan 
penempatan petugas pelayanan

kesehatan, bidang pendidikan menekankan pada pemerataan dan pembukaan jangkauan pendidikan sejak usia dini sampai perguruaan tinggi. Sementara itu, pada bidang pembinaan aparatur pemerintahan diarahkan pada pendidikan dan pelatihan serta bimbingan teknik (wawancara, 10/10/09).

Tentunya untuk menjawab dan mengarahkan beberapa bidang strategis ini dalam mewujudkan misi pembangunan maka langkah-langkah yang harus ditempuh adalah; (1) adanya perumusan agenda dalam proses tindak lanjut, (2) perumusan target capaian untuk masingmasing program, (3) penetapan alokasi pemberdayaan dan anggota, (4) bagaimana mengimplementasikan, (5) pengawasan, (6) evaluasi untuk menjamin tindak lanjut yang efektif .

Di sisi lain, mewujudkan atau mengimplementasikan misi di beberapa bidang ini harus sudah dirasakan oleh masyarakat secara luas di Kota Tidore Kepulauan, namun ada pandangan yang berbeda dengan apa yang dikatakan Wali Kota terpilih Ahmad Mahifa, terkait dengan visi dan misi pembangunan pemerintahan dibidang kesehatan, pendidikan dan pembinaan aparatur bahwa: Bidang-bidang yang kami sebutkan di atas sudah tertuang dalam Rencana Pembagunan Jangka Menengah Daerah Kota Tidore Kepulauan, dan akan dilaksanakan sesuai dengan anggaran yang ada (wawancara, 10/10/09).

Melihat pandangan dan gambaran dari Wali Kota di atas, maka bidang yang disebutkan ini masih dilihat sebagai persoalan-persoalan daerah yang krusial dan memiliki peran untuk mendorong ke arah implementasikan kebijakan pembangunan yang bermartabat mandiri dan memiliki budaya yang handal. Mendukung pandangan Wali Kota dan Unsur DPRD Kota Tidore Kepulauan di atas bahwa mewujudkan visi dan misi di Kota ini masih pada taraf dan tingkatan untuk mempersiapkan diri dari sumber daya yang dimilikinya. Dalam pandangan Fataruddin Soleman (Sekertaris Bappeda Kota Tidore Kepulauan) mengatakan bahwa:

Yang pertama adalah menyiapkan sumber daya aparatur di bidang kesehatan, bidang pendidikan pemerintah, kedua; penyiapan sarana dan prasarana untuk menunjang bidang pendidikan kesehatan dan penelitian dalam rangka peningkatan mutu 
pendidikan di tingkat masyarakat, ketiga; setiap tahun anggaran untuk bidang kesehatan dan pendidikan disiapkan $20 \%$ dari total APBD yang diusung (wawancara, 10/10/09).

Dengan demikian untuk mewujudkan langkah-langkah visi dan misi ini, tentunya diwujudkan dengan menentukan program dan kegiatan yang sinergis dengan Rencana Pembangunan Jangka Menengah, Renstra, SKPD, dan RKPD. Hal lain juga yang turut mengimplementasikan terlaksanya visi dan misi ini adalah bahwa pengelolaan sumber anggaran yang efektif, efisien dan tepat sasaran. Bahkan monitoring, evaluasi, dan pengawasan program dan kegiatan adalah dilaksanakan ke depan kemudian menjadi umpan balik di tahun mendatang.

Pada kesempatan yang lain, Sekertaris Kota Tidore Kepulauan menilai bahwa mewujudkan kualitas sumber daya manusia dalam rangka pelaksanaan misi untuk mewujudkan visi pembangunan, sehingga terciptanya Kota Tidore yang beriman, mandiri, maju dan berperadaban yang dilakukan untuk meningkatkan sumber daya manusia melalui pelayanan kesehatan, pendidikan, dan pembinaan aparatur pemerintahan. Menurut Sekertaris
Tikep untuk mewujudkannya harus diarahkan pada

(1) pelayanan kesehatan, yang paling pokok adalah peningkatan akses masyarakat terhadap pelayanan kesehatan yang berkualitas, (2) aspek pendidikan yang paling pokok adalah peningkatan pemerataan dan keterjangkauan masyarakat dalam mengejar pendidikan sejak usia dini sampai dengan pendidikan tinggi, dengan sarana yang memadai dan tenaga kependidikan yang handal, peningkatan sumber daya aparatur dengan kemampuan membangun (wawancara, 11/10/09).

Hasil wawancara di atas, menjelaskan implementasi kebijakan program misi berupa bidang kesehatan, pendidikan dan peningkatan sumber daya manusia memiliki substansi penting, karena sangat diharapkan masyarakat Kota Tidore Kepulauan untuk lebih maju dalam mengembangkan sektor tersebut di atas.

\section{Dimensi Disposisi}

Untuk meningkatkan pembangunan infrastruktur sosial, ekonomi dan pemerintahan sebagai dimensi dalam misi pembangunan pemerintahan Kota Tidore Kepulauan, para aktor kebijakan dan elit politik, tidak saja memiliki pengtetahuan 
dalam menentukan dan membangun kebijakan tetapi, komitmen, nilai kejujuran, kepercayaan dan bahkan nilai-nilai demokrasi menjadi instrumental utama dalam implementasi misi menuju pembangunan yang mandiri, bermartabat bahkan berperadaban. Untuk hal ini Sekertaris Kota Tidore mengatakan bahwa: Sebagaimana diketahui bahwa perencanaan yang baik itu belum cukup tanpa didukung kemampuan SDM yang memadai, dengan kepercayaan dan SDM yang handal, tak cukup namun perlu komitmen. Untuk itu kita sangat berkomitmen pula untuk terus menerus memacu SDM aparatur sekaligus mengasuh komitmennya yang bersinergi untuk mewujudkan visi dan misi pembangunan ini untuk kemajuan kota yang nantinya bisa setara dengan daerah lainnya walaupun disana-sini masih harus dibenahi dari sisi SDM dan Kelembagaan (wawancara, 11/10/09).

Wawancara di atas menjelaskan bahwa dalam mewujudkan misi pembangunan pemerintahan Kota Tidore Kepulauan, tidak hanya mengandalkan sumber daya manusia yang berkualitas, namun komitemen, kepercayaan dan karakter dari aktor kebijakan pembangunan menjadi unsur yang penting dalam penyelenggaraan pemerintahan. Karena dengan modal dan dasar inilah pembangunan dapat berjalan sesuai dengan tujuan ditetapkannya. Komitmen dan kepercayaan dalam pembangunan juga di jelaskan Sekertaris Bappeda Kota Tidore Kepulauan bahwa; Dengan berbekal kemampuan dan komitmen terhadap kebijakan yang jelas, ditetapkan dalam perencanaan, maka implementasi visi dan misi dapat berjalan secara konsisten untuk pencapaian misi pembangunan kota tidore (wawancara, 11/10/09).

Konsistensi akan komitmen dalam penyelenggaraan pemerintahan harus menjadi perhatian dan isu utama untuk dikelola, karena diakui bahwa Kota Tidore Kepulauan masih memiliki kelemahankelemahan dalam konteks pembangunan yang menjamin partisipasi dan pelayanan publik secara umum. Olehnya disposisi dan kemampuan dalam membangun Kota Tidore Kepulauan harus menjadi tujuan utama. Wali Kota Tidore Kepulauan mengatakan bahwa;

Kemampuan, komitmen dan konsistensi ini yang dibutuhkan, karena di kota ini masih kurang para aparat yang memiliki kemampuan tersebut. Bahkan ketiga hal ini bisa menjamin apa yang kita rencanakan dapat terlaksana sesuai 
harapan tentang pengelolaan pemerintahan yang baik, pelaksanaan pembangunan yang baik, dan lebih $b$ aik dan penting adalah pelayanan masyarakat, yang semakin baik (wawancara, 11/10/09).

Di sisi lain, kemampuan akan pengelolaan pembangunan dengan komitemen dan kepercayaan akan menumbuhkan sikap membangun negara atau bangsa bahkan Kota menjadi lebih ringan dan bertanggungjawab. Jika komitmen dijalankan secara baik, maka pemerintahan akan berjalan dengan dukungan dan kepercayaan publik di Kota Tidore Kepulauan. Hal ini dikatakan oleh Unsur Dewan Perwakilan Rakyat Daerah Kota Tidore Kepulauan bahwa; Karena dengan kemampuan dan komitmen yang baik dalam konteks pemerintahan. Maka pengelolaan pemerintahan akan berjalan baik bahkan berakses pada pelaksanaan pembangunan dan pelayanan masyarakat yang baik pula (wawancara, 11/10/09).

Dengan demikian bahwa pengelolaan pemerintahan bisa baik jika, para penyelenggara pembangunan memiliki komitmen yang sama dalam mewujudkan dan mengembangkan misi untuk diimplementasikan secara baik pula. Dan hal ini akan dampaknya dapat dinikmati atau dirasakan masyarakat Kota Tidore Kepulauan. Dalam arti bahwa dimensi disposisi dalam wujud komitmen, kejujuran dan menerapkan nilai-nilai demokrasi, ketika pejabat publik di Kota Tidore Kepulauan terlihat dalam praktek pemerintahan sehari-hari.

\section{Dimensi Struktur Birokrasi}

Salah satu dimensi dari implementasi kebijakan publik oleh George Edwar III, adalah "struktur birokrasi". Dimensi ini juga memiliki kekuatan untuk keberhasilan suatu pemerintahan. Implementasi akan struktur birokrasi meniscayakan kemudahan dan bahkan mengurangi pemborosan uang negara dalam penyelenggaraan pemerintahan. Dimensi ini juga menentukan dan mengurangi konflik kepentingan di antara aktor dari elit politik. Di akui bahwa struktur birokrasi yang ada di Kota Tidore Kepulauan masih membutuhkan analisis untuk tentang aturan main, komitmen dan kemampuan dalam mengembangkan fungsinya, hal ini dikatakan Wali Kota Tidore Kepulauan bahwa;

Bagi saya untuk kondisi Kota Tidore saat ini, di pemerintahan belum cukup baik. Lagi pula berkonsekuensi dengan 
ketentuan peraturan dan perundangundangan, sehingga kemampuan, komitmen dan konsistensi yang harus diasah agar tugas pokok dan fungsinya dapat berjalan dengan baik (wawancara, 11/10/09).

Struktur birokrasi yang dimiliki pemerintahan Kota Tidore Kepulauan masih membutuhkan perubahan-perubahan di sana sini, mengingat fungsinya belum optimal dalam melaksanakan tugas-tugas diinternal lembaga. Bahkan belum secara baik mengimplementasikan Rencana Pemabangunan Menengah Daerah (RPJMD) di Kota Tidore Kepulauan, Sekertaris Bappeda mengatakan ketika diwawancarai bahwa;

Belum cukup dalam memudahkan penetapan struktur kelembagaan birokrasi belum sesuai dengan ketentuan dan peraturan perundang-undangan, dimana struktur birokrasi yang ada saat ini sudah memiliki uraian tugas namun, belum optimal pelaksanaannya yang sesuai dengan upaya implementasi RPJMD Kota Tidore Kepulauan (wawancara,11/10/09).

Dalam pelaksanaan misi terkait dengan implementasi kebijakan pembangunan secara umum, harus disesuaikan dengan aturan main atau peraturan dan perundang-undangan yang berlaku karena, untuk melakukan sistem perampingan struktur birokrasi memerlukan tujuan dan latar belakang yang jelas, sehingga pertimbangan-pertimbangan menajdi unsur penting untuk mengurangi orientasi pemborosan bagi penyelenggaraan pemerintahan. Terkait dengan masalah di atas, maka, Sekertaris Kota Tidore Kepulauan mengungkapkan bahwa;

Menurut kami ya, mungkin belum terlalu ideal, tapi yang diharapkan keluarannya dapat berfungsi secara maksimal. Perlu dikethui bahwa struktur birokrasi itu kan berdasarkan ketentuan PP No 41 tentang organisasi perangkat daerah. Kami sudah mendesain berdasarkan ketentuan tersebut dan berdasarkan pertimbangan kondisi daerah, kemampuan pembiayaan dan strategi pengembangan dalam implementasi visi dan misi pembangunan Kota Tidore Kepulauan. Di samping itu, perkembangan pembangunan kawasan strategis dan cepat tumbuh kami galakkan saat ini sesungguhnya telah bergerak dari pemetaan wilayahnya sekarang itu pula pada pengembangan infrastruktur kawasan antara lain utilitas perkotaan(wawancara, 11/10/09)

Mewujudkan ide-ide pembangunan pemerintahan di Kota Tidore Kepulauan dalam konteks implementasi kebijakan 
yang terkait dengan struktur birokrasi, banyak hal yang harus didoring sebagai keberhasilan dari implementasi program yang telah disuung. Perampingan akan struktur birokrasi dalam mewujudkan misi pembangunan Kota Tidore dalam konteks implementasi program pembangunan ke depan. Dalam hal ini menurut Unsur DPRD Kota Tidore Kepulauan Mengatakan bahwa:

Saat ini dapat dikatakan baik, walaupun demikian idealnya masih dapat dilakukan perampingan struktur dengan prinsip struktur yang sempit kaya fungsi dan dari aspek pembiayaan masih efisien sebagai contoh, untuk Dinas Pendapatan Daerah, bagian keuangan Setda dan perlengkapan dapat digabungkan dalam satu SKPD yakni satuan Karya Perangkat Daerah, misalnya Badan Pengelolaan Keuangan dan Aset Daerah. Menurutnya perkembangan pembangunan kawasan strategis dan cepat tumbuh dan berkembang dalam proses implementasi kebijakan semestinya di susuin dalam dokumen perencanaan dan pemekaran wilayah. Hal ini harus disosialisasikan mulai dari perda tentang RUTRW tetapi karena kawasan strategis dan cepat tumbuh itu dalam pengembangan diperlukan konsentrasi khusus, maka harus dengan pembiayaan dan aspek regulasi yang lebih menjamin upaya pengembangan(wawancara, 11/10/09).

Hasil wawancara unsur DPRD di atas, menunjukkan bahwa tujuan perampingan struktur birokrasi mengindikasikan memperkecil struktur dan menambah fungsi akan lebih baik dalam implementasi kebijakan pembangunan Kota Tidore Kepulauan. Di sisi lain bahwa reformasi akan struktur birokrasi sebagai salah satu dimensi implementasi kebijakan akan sangat berpengaruh dalam mewujudkan misi pembangunan. Hal ini karena struktur birokrasi juga menentukan berjalannya sistem dalam mengelola pemerintahan di Kota Tidore Kepulauan.

\section{Dimensi Isi Kebijakan}

Dalam dimensi isi kebijakan berupa misi pembangunan Kota Tidore Kepulauan bermplikasi pada aktor-aktor kebijakan yang dapat mengendalikan berbagai konsep yang diusung, karena masa depan implementasi misi dari pemerintahan yang sedang berjalan memberikan inspirasi bahwa aktor kebijakan seperti legislatif dan eksekutif sangat menentukan dan mempengaruhi semua isi kebijakan pembangunan pemerintah ke depan. Dari kedua aktor ini boleh jadi mendominasi kepentingan kelompok masing-masing 
dengan mengatasnamakan kepentingan rakyat, sebagaimana dikatakan Sekertaris Kota Tidore Kepulauan bahawa;

Sangat di pengaruhi oleh aktor kebijakan legislatif dan eksekutif, karena pengambilan keputusan atas persetujuan lembaga tersebut. Karena itu boleh dibilang bahwa ini adalah sebuah keputusan politik tetapi yang terpenting dari sini yaitu kebijakan yang dihasilkan di dasarkan pada kepentingan dan pertimbangan rasional dan komitmen. Tidak semua keputusan itu didasarkan pada dokumen perencanaan di atasnya. Akan tetapi sering kepentingan pribadi, atau kelompok mendominasi yang mengatasnamakan kepentingan rakyat untuk mewujudkan visi dan misi pembangunan Kota Tidore Kepulauan (wawancara,11/10/09).

Misi pembangunan secara ideal harus mengikuti aturan main yang berlaku di saat suatu perumusan kebijakan ditetapkan sebagai agenda yang mendesak. Wawancara di atas, lebih menonjolkan kepentingan pribadi dan kelompok bahkan partai dalam mengelola pemerintahan atau dalam mewujudkan misi pembangunan. Artinya terkait dengan kepentingan para aktor dalam implementasi kebijakan publik. Bagi kepentingan rakyat dianggap masih relatif rendah atau belum terjadi pemerataan-pemerataan, dalam hal ini di tegaskan Wali Kota Tidore (Ahmad Mahifa) bahwa;

Sejauh ini memang ada kepentingan tetapi kepentingan yang rasional dibiayai dengan rencana pengembangan daerah sebagai suatu upaya untuk meningkatkan kesejahteraan rakyat, tetapi kebijakan yang dihasilkan pun relatif masih harus ada pembenahan-pembenahan ke dalam lembaga, sehingga para aktor kebijakan meninggalkan kepentingan-kepentingan pribadi (wawancara, 11/10/09).

Di akui oleh Wali Kota bahwa perlu ada pembenahan-pembenahan di tubuh birokrasi pemerintah Kota Tidore Kepulauan, dimana para aktor kebijakan dan elit politik lainnya untuk membatasi kepentingan-kepentingan mereka. Sementara itu, dalam pandangan yang berbeda bahwa secara riil pengaruh lembaga dalam implementasi program visi dan misi begitu kuat. Dalam hal ini antara harapan dan kenyataan sangat berbeda, misalnya apa yang dirumuskan melalui RPJMD belum tentu ada realisasi pada tataran praksis. Hal ini dikatakan Unsur DPRD bahwa;

Sangat dipengaruhi oleh lembaga, sebagai contoh bahwa program yang 
telah dirumuskan terkadangan tidak diaplikasikan dilapangan sesuai rencana yang disusun. Misalnya ada di APBD, tetapi terkadang bias dari arah kebijakan umum yang ditetapkan dengan standar pada RPJMD dan RKPD (wawancara,11/10/09).

Keberhasilan implementasi kebijakan program visi dan misi ke depan, maka harus merubah paradigma yang sesuai dengan kondisi masyarakat yaitu apa yang menjadi kebutuhan yang ditetapkan sebagai rencana strategis kebijakan pembangunan yang mendorong bagi pimpinan ke depan yang baik lagi. Namun dalam konteks ini kebijakan ini, peluang dan kesempatan pejabat publik dapat membatalkan dan sekaligus intervensi program dalam misi pembangunan yang diwujudkan.

\section{Dimensi Konteks lingkungan Implementasi}

Dalam konteks lingkungan kebijakan visi dan misi pembangunan mengisyaratkan bahwa kekuasaan, kepentingan dan strategi aktor dalam pembangunan memiliki pengaruh, karena proses implementasi kebijakan untuk mencapai sasaran pembangunan Kota Tidore melalui banyak aktor yang terlibat didalamnya. Pengaruh aktor dalam kekuasaan diorientasikan melalui intervensi program-program dalam mewujudkan misi pembangunan. Namun interfensi dari visi dan misi ini paling tidak, minimal berpengaruh pada kepentingan dan kekuasaan dalam implementasi program pembangunan Koata Tidore. Hal ini dikatakan Sekertaris Bappeda Kota Tidore Kepulauan (Fatarudin Soleman) mengatakan ketika diwawancarai;

Memang berpengaruh tetapi tidak begitu banyak karena aktor yang dimaksudkan dalam strategi mewujudkan visi dan misi ini itu harus dilakukan secara rasional dan objektif dalam kerangka melaksanakan program-program yang telah ditawarkan khususnya di Todore Kepulauan (wawancara,11/10/09).

Kepentingan akan kekuasaan merupakan hal biasa terjadi dalam dunia politik, apalagi mewujudkan dalam konteks implementasi visi dan misi pembangunan kota Tidore Kepulauan. Akan tetapi secara ideal politik yang baik adalah politik yang dapat mencerahkan negara dan masyarakatnya. Perjuangan akan kekuasaan dalam mewujudkan pembangunan Kota Tidore Kepulauan. Jadi secara substantif kekuasaan dalam politik harus mengindikasikan perjuangan dan kepentingan masyarakat. Terkait dengan 
kepentingan kekuasaan ini, Sekertaris Kota

Tidore menguraikan bawah;

Menurut kami bahwa unsur kekuasaan, kepentingan dan strategi aktor sesuatu yang terpenting. Apapun kepentingan harus mengacuh pada implementasi visi dan misi, memang perlu diakui bahwa siapa yang tidak memiliki kepentingan ketika berhadapan dengan kekuasaan, namun harus juga mempertimbangkan kepentingan masyarakat, dan keuangan daerah (wawancara, 11/10/09).

Kekuasaan politik dalam suatu pemerintahan mengisyaratkan kekuasaan akan kepentingan elit politik yang memegang legitimasi kekuasaan, dimana mewujudkan konsep dan program pembangunan ke depan. Intinya bahwa pengaruh kekuasaan dan kepentingan aktor harsu didasarkan pada program misi elit politik yang sedang memimpin pemerintahan. Hal ini diungkapkan Wali Kota Tidore Kepulauan bahwa:

Masalah kepentingan dalam kekuasaan suatu lembaga merupakan hal biasa, karena apapun kekuasaan pasti memiliki pengaruh untuk menjaga legitimasi dan kepentingannya dalam rangka melaksanakan visi dan misi pembangunan Kota Tidore Kepulauan. (wawancara, 11/10/09.
Dalam konteks kepentingan kekuasaan pada implementasi kebijakan. Masalah visi dan misi merupakan unsur atau komponen penting dalam keberhasilan dan atau kegagalan dalam implementasi kebijakan pembangunan, karena dalam konteks ini keberhasilna dan kegagalan juga ditentukan oleh penguasa yang memiliki legitimasi dalam pemerintahan.

\section{F. P E N U T U P}

\section{Kesimpulan}

Dari hasil pembahasan pada bagian sebelumnya, penelitian ini menghasilkan kesimpulan yang terdiri:

a. Dimensi komunikasi, ditemukan bahwa untuk implementasi kebijakan program pembangunan pada unsur keagamaan dinilkai sejak tahapan perencanaan yang dilakukan melalui tingkat Musrembang (Kecamatan Desa dan Kelurahan), melalui rapat, forum komunikasi. Dari beberapa tahapan ini terkadang bias, dimana rumusan materi kebijakan yang dikomunikasikan pada tingkat musrembang seharusnya menjadi konsensus, namun pada tahapan selanjutnya tidak terakomodasi dalam bentuk kebijakan yang 
diimplementasikan. Faktanya pada musrembang tingkat desa/kelurahan terumuskan 5 (lima) program perioritas. namun tingkat kecamatan pengajuan program perioritas tersebut tereduksi dalam bentuk perioritas kecamatan, dan tidak semua prioritas desa/kelurahan terakomodir. Proses reduksi ini terjadi pula pada tingkat selanjutnya, yakni tingkat rapat kerja perencanaan pembangunan ditingkat kota. Kondisi ini memperlihatkan bentuk komunikasi kebijakan yang tidak konsisiten sehingga memunculkan rasa tidak puas bagi masyarakat terkait penyelenggaraan pembangunan yang tidak bersesuaian dengan kebutuhan masyarakat. Bahkan lokakarya, seminar, media masa belum memberikan hasil yang memuaskan bagi masyarakat di Kota Tidore Kepulauan. Ini terkait dengan dimensi komunikasi yang belum maksimal dalam mencapai target dan sasaran.

b. Sumber daya, ditemukan masih rendahnya SDM bidang kesehatan dan pelayanan kesehatan, rendahnya akses pelayanan pendidikan dari Sekolah Dasar sampai Perguruan Tinggi, rendahnya SDM bidang pendidikan, dan SDM apartur pemerintahan. Ini menunjukkan belum optimalnya implementasi misi atau program kebijakan pembangunan bidang-bidang yang disebutkan di atas.

c. Pada dimensi disposisi, masih kurangnya kemampuan untuk berkomitmen dalam melaksanakan tugas pemerintahan dengan mempertimbangkan kepercayaan dan konsistensi pada aturan dan perundang-undangan. Karena komitmen dapat merangsang dinamika penyelenggaraan pemerintahan, bahkan masih kurangnya aparat yang memiliki komitmen di Kota Tidore Kepulauan.

d. Struktur birokrasi belum cukup memadai antara kemampuan daerah sering bertentangan dengan peraturan dan perundang-undangan yang berlaku atau regulasi yang ditetapkan. Bahkan belum cukup dalam memudahkan dan menetapkan struktur birokrasi kelembagaan belum sesuai dengan aturan, belum optimalnya pelaksanaan Rencana Pembangunan Jangka Menengah Derah (RPJMD).

e. Dimensi isi Implementasi Kebijakan. Kegagalan sebuah implementasi kebijakan karena dipengaruhi oleh aktor kebijakan seperti eksektif dan 
legislatif atas keputusan politik yang mengarah pada kepentingan pribadi dan kelompok. Dalam kekuasaan kepentingan tetap ada dan dapat mempengaruhi isi kebijakan yang diputuskan berpihak pada kepentingan penguasa.

f. Dimensi konteks lingkungan kebijakan, dipengaruhi oleh kepentingan penguasa dalam rangka mengimplementasikan misi pembangunan pemerintahan. Untuk perlakuan penguasa dalam melegetimasi kepentingan ini menjadi sesuatu yang wajar.

\section{Saran}

Saran yang dapat disampaikan dari hasil penelitian ini adalah:

a. Pada dimensi komunikasi, semua aktor harus memposisikan diri untuk mengkomunikasikan misi melalui; (1) Musrembang, (2) rapat kerja, (3) forum konsolidasi, (4) lokakarya, (5) seminar, (6) implementasi program disertai pembinaan dan penataan lembaga.

b. Dalam mengembangkan sumber daya pembangunan Kota Tidore Kepulauan bahwa saatnya pemerintah Kota Tidore Kepulauan meningkatkan sumber daya manusia diberbagai bidang kehidupan. Hal ini disesuaikan dengan perumusan visi dan misi pembangunan. Di sisi lain, dalam meningkatkan kualitas pendidikan dari Sekolah Dasar sampai Perguruan Tinggi, tenaga kependidikan perlu diberi tunjungan khusus dalam merangsang kualitas kerja.

c. Pada dimensi Disposisi, diharapkan setiap aparatur agar meningkatkan kepercayaan dan memperteguh komitmen serta konsistensinya pada tanggungjawab pelaksanaan tugas pemerintahan untuk melayani masyarakat di Kota Tidore Kepulauan.

d. Pada dimensi Struktur birokrasi, harus adanya penetapan struktur birokrasi sesuai dengan situasi dan kondisi internal lembaga dan wilayahnya di Kota Tidore Kepulauan, mempertahankan dan melaksanakan uraian tugas, diharapkan struktur berjalan secara ideal, bahkan adanya sistem perampingan struktur birokrasi yang sempit tetapi kaya fungsi.

e. Dalam mempertimbangkan dimensi isi kebijakan, maka diharapkan bahwa (1) materi kebijakan yang diimplementasikan, secara ideal harus sesuai dengan dokumen perencanaan yang telah diputuskan dalam Musrembang, dan RPJMD, (2) isi 
implementasi kebijakan pembangunan harus mempertimbangkan kepentingan masyarakat, bukan kepentingan elit politik, (3) kepentingan harus secara rasional demi kepentingan pengembangan daerah.

f. Dalam konteks lingkungan implementasi, diharapkan bahwa pada saatnya elit politik merubah paradigma untuk mendahulukan kepentingan masyarakat, dan mendahulukan program secara rasional, yang dibutuhkan masyarakat, dimana sesuai dengan perumusan misi pembangunan Kota Tidore Kepulauan.

\section{DAFTAR PUSTAKA}

Abdul Wahab, Solichin. 1997. Analisis Kebijaksanaan: Dari Formulasi ke Implementasi Kebijaksanaan Negara. Edisi Kedua. Bumi Aksara. Jakarta.

-1989. Analisis Kebijaksanaan Negara:Teori dan Aplikasinya. PT Danar Wijaya, Brawijaya University Press. Malang.

Anderson, James E. 1979. Public Policy Making. New York. NJ: Holt Reinhartnwinston.

Bryson. J.M., (2007). Perencanaan Strategis Bagi Organisasi Sosial. Yogyakarta:

Pustaka Pelajar.
Depdagri, (2004). Undang-Undang RI Nomor 25, Tahun 2004 tentang SistemPerencanaan Pembangunan Nasional. Jakarta: Sinar Grafika.

Depdagri, (2004). Undang-Undang RI Nomor 32, Tahun 2004 tentang Pemerintahan Daerah. Jakarta: Sinar Grafika.

Hasan. M.I., (2002). Pokok-Pokok Materi Metodologi Penelitian dan Aplikasi. Jakarta: Ghalia Indonesia.

Indra Bastian., (2006). Sistem Perencanaan dan Penganggaran Pemerintah Daerah Di Indonesia. Jakarta: Salemba Empat.

Miron Weiner. (1986). Modernisasi Dinamika Pertumbuhan. Yogyakarta: Gajah Mada University Press.

Moeleong,J.Lexy.2002.Metode penelitian Kualitatif.PT Remaja Rosdakarya

Nasution.1988.Metode Penelitian Naturalis Kualitatif. Tarsito.Bandung

Nugroho, Riant. 2006. Kebijakan Publik untuk Negara Berkembang: Modelmodel Perumusan, Implementasi, dan Evaluasi. Jakarta. Elex Media Kompotindo.

Nurlan Darise. (2008). Pengelolaan Keuangan Pada Satuan Kerja Perangkat Daerah (SKPD). Jakarta: PT.Indeks.

Rahmat, (2009). Teori Administrasi dan Manajemen Publik. Jakarta: Pustaka Arif. 
Subarsono. 2008. Analisis Kebijakan Publik, Konsep, Teori, dan Aplikasi. Yogyakarta. Pustaka Pelajar.

Siagian S.P. (1978). Administrasi Pembangunan. Jakarta: PT. Gunung Agung.

Widodo, Joko. 2009. Analisis Kebijakan Publik: Konsep dan Aplikasi Analisis Proses Kebijakan Publik. Jakarta. Bayumedia Publising. 